\title{
Bovine tunica albuginea conserved in honey as xenograft for cystoplasty in rats
}

\author{
Aline Ferreira Rodrigues ${ }^{1}$ (D) Cecília Ribeiro Castañon ${ }^{1}$ (D) Tábata Maués ${ }^{1^{*}}$ (D) \\ Carla Ferreira Farias Lancetta ${ }^{2}$ (D) Edmundo Jorge Abílio $^{3}$ (i) \\ Viviane Alexandre Nunes Degani ${ }^{2}$ (D) Maria de Lourdes Gonçalves Ferreira ${ }^{1}$ (D)
}

${ }^{1}$ Faculdade de Veterinária, Universidade Federal Fluminense (UFF), 24220-000, Niterói, RJ, Brasil. E-mail: tabatamaues@id.uff.br. ${ }^{*}$ Corresponding author.

${ }^{2}$ Departamento de Morfologia, Universidade Federal Fluminense (UFF), Niterói, RJ, Brasil.

${ }^{3}$ Departamento de Patologia e Clínica Veterinária, Universidade Estadual do Norte Fluminense Darcy Ribeiro (UENF), Campos dos Goytacazes, RJ, Brasil.

\begin{abstract}
Urinary bladder damages leading to few viable bladder tissue available might demand a challenging reconstructive surgery. In this context, biomaterials are valid alternatives for bladder reconstruction. This study evaluated the bovine tunica albuginea fragment as graft material for cystoplasty in rats and honey-preserved implant viability. Thirty Wistar rats were assigned to two groups: (1) a test group (T) with a circular 1.0-cm-diameterbovine tunica albuginea graft application in the apex region by a continuous absorbable (Polyglactin 910 5-0) suture with stitching of all bladder layers and (2) a simulation group (S) in which animals underwent only partial cystectomy. In addition, each of these groups was further divided into three subgroups according to euthanasia period on post-surgery day 7, 15 and 30.Two animals had self-limiting hematuria at postsurgical period. At necropsy, frequent crystals and adhesion to the peritoneum were observed. At the histopathological evaluation, animals from the T group euthanized by 15th postoperative day had layers disorganization and initial muscle development, while $T$ group rats euthanized by 30th postoperative day showed complete urothelization. Urothelization pattern was similar in both groups. Moreover, the muscular layer formation was present in both groups, but more evident in $S$ group animals. Nevertheless, inflammatory infiltrate and neovascularization were remarkably more intense in T group rats.It might be concluded that bovine tunica albuginea graft was successful in repairing rats'bladder, being a good biomaterial option in reconstructive urinary vesicle surgery.
\end{abstract}

Key words: cystectomy, reconstruction, biomaterials, urinary bladder.

Túnica albugínea bovina conservada em mel como xenoenxerto na cistoplastia em ratos

RESUMO: Lesões na vesícula urinária que culminem em pouco tecido vesical viável podem demandar cirurgias reconstrutivas desafiadoras. Neste contexto, biomateriais são alternativas válidas para a reconstrução da bexiga. O objetivo deste trabalho foi avaliar a túnica albugínea bovina como material para enxerto na cistoplastia em ratos, assim como a viabilidade deste implante preservado em mel. Trinta ratos Wistar foram divididos em dois grupos: (1) um grupo teste (T), no qual os animais foram submetidos a cistectomia parcial seguida de cistoplastia com aplicação do enxerto circular com 1,0cm de diâmetro de túnica albugínea bovina na região do ápice com sutura absorvivel (Poliglactina 910 5-0) em padrão contínuo englobando todas as camadas da bexiga; e (2) um grupo simulação (S), cujos ratos realizaram apenas cistectomia parcial. Além disso, cada grupo foi posteriormente dividido em três subgrupos de acordo com a data de eutanásia no dia 7, 15 ou 30 de pós-operatório.Dois animais apresentaram hematúria autolimitante no periodo de observação pós-operatória. Na necrópsia, notaram-se cristais frequentes e aderências entre bexiga e peritônio. Na avaliação histopatológica, animais do grupo Teutanasiados com 15 dias de pósoperatório apresentavam camadas vesicais desorganizadas e formação de musculatura inicial na bexiga, enquanto aqueles eutanasiados com 30 dias de cirurgia mostraram urotelização completa. O padrão de urotelização foi semelhante nos dois grupos. Além disso, a formação da camada muscular esteve presente em ambos os grupos, porém mais evidente nos animais do grupo $S$. No entanto, o infiltrado inflamatório bem como a neovascularização foram notavelmente mais intensos nos ratos do grupo T.Pode-se concluir que o enxerto de túnica albugínea bovina foi bem sucedido no reparo da vesícula urinária de ratos, demonstrando ser uma boa opção de biomaterial para cirurgias reconstrutivas da vesícula urinária.

Palavras-chave: cistectomia, reconstrução, biomateriais, vesícula urinária.

\section{INTRODUCTION}

Traumatic, inflammatory, and neoplastic lesions are common conditions that might cause urinary bladder damage, which demand reconstructive intervention (GRECA et al., 2002). Surgical closure might be a real challenge when few viable bladder tissue is available. In this context, biomaterials are valid alternatives for urinary vesicle reconstruction.

The ideal material for bladder reconstruction should keep up with its compliance and volume without annoyed immunological changes 
in graft receptor. Studies have shown a urinary vesicle natural capacity for self-repair and modeling (GRECA et al., 2004).

Twobladder regeneration and augmentation techniques have been proposed previously. The former was based on in vitro epithelial cell culture (LI et al., 2016). The second technique is grounded on developing allogenic or xenogeneic biodegradable materials from acellular collagen matrix (IIJIMA et al., 2007; ALBRECHT et al., 2015).

Biomaterials such as acellular bladder matrix (ZHAO et al., 2015; LI et al., 2016), pericardium (ALBRECHT et al., 2015), tunica vaginalis (WONGSETTHACHAI et al., 2011; FARIA et al., 2020), swine intestinal submucosa (ROSSETTO et al., 2013), peritoneum (OLIVEIRA et al., 2008), amniotic membrane (IIJIMA et al., 2007; ADAMOWICZ et al., 2012) and ileum (FERREIRA et al., 2005) have been reported in bladder repair surgery. Several studies have shown the tunica albuginea as a useful biomaterial due to its low cost, easy collection, conservation, and processing (QUEIROZ et al., 2012; OLIVEIRA et al., 2015; MORAES et al., 2017, FERREIRA et al., 2020).

Tunica albuginea is a thick capsule of dense connective tissue, which surrounds the testicle (JUNQUEIRA \& CARNEIRO, 2017). It is rich in collagen fibers organized in two layers: the external has longitudinal collagen fibers orientation and the internal layer has circularly bundle dispositions, which enable tissue tensile strength (QUEIROZ et al., 2012). Considering that bovine tunica albuginea is an available, easy handling and inexpensive biomaterial, this research was motivated by the lack of reports of its use as xenograft in rats' urinary vesicle.

Honey has been shown promising results preserving different types of tissues such as skin (SUBRAHMANYAM, 1993), cornea (ABRAMOV \& MARKICHEVA, 1983), bone (ALIEVI et al., 2007; FERREIRA et al., 2018) and bovine tunica albuginea (MEDEIROS et al., 2020). In addition, it has been identified as an antibacterial agent and wound healing facilitator (SANTOS, 2012).

This research evaluated the bovine tunica albuginea fragment as graft material for cystoplasty in rats and honey-preserved implant viability.

\section{MATERIALS AND METHODS}

The tunica albuginea was obtained from an open orchiectomy technique of a healthy six-monthold crossbred calf. The tunica was extracted sterilely and preserved in organic raw honey in such a way that the entire fragment got in contact with the solution. Then, it was stored at room temperature (not above $35^{\circ} \mathrm{C}$ ) for at least 60 days. The honey was orange flower origin and was produced in artificial hives at Nova Friburgo (Rio de Janeiro, Brazil) region. The honey has not been diluted.

A total of 30 four-month-old male Wistar rats were selected for this study.The animals were housed in individual boxes with saw dust bed, kept under temperature controlled $\left(22 \pm 2{ }^{\circ} \mathrm{C}\right), 12 \mathrm{~h}$ lightdark cycles, food and water ad libitum.

Wistar rats were assigned to two groups: (1) a test group (T), whose animals ( $\mathrm{n}=$ 15) underwent partial cystectomy followed by cystoplasty with bovine tunica albugineagraft application; and (2) a simulation group (S), in which animals $(n=15)$ underwent only partial cystectomy. In addition, each of these groups was further divided into three subgroups $(\mathrm{n}=5)$ according to euthanasia period on post-surgery day 7, 15 and 30 . Therefore, we had the following subgroups: T7, T15, T30, S7, S15, and S30.

Anesthetic induction was achieved with ketamine $(75 \mathrm{mg} / \mathrm{kg})$ and midazolam $(10 \mathrm{mg} / \mathrm{kg})$ combined with intraperitoneal injection in both $\mathrm{T}$ and $\mathrm{S}$ group. After general anesthesia, abdominal trichotomy and antissepsia (1\% chlorhexidine digluconate and alcohol) of the operative field were performed. The animals were placed in dorsal decubitus position and underwent median longitudinal retro-umbilical laparotomy with an approximately two centimeters incision. Then, the bladder was exposedand emptied by cystocentesis with a syringe and $0.38 \times 13 \mathrm{~mm}$ needle. Two seromuscular suture repair were placed. Then, a partial cystectomy cut out a fragment of approximately $1 / 3$ bladder size (the apex and part ofthe vesicle body). After partial cystectomy, T group animals had a circular 1.0-cm-diameter bovine tunica albuginea fragment positioned in the apex region and grafted in the bladder. The tunica fragment has been previously immersed in sterile $0.9 \% \mathrm{NaCl}$ solutionfor $30 \mathrm{~min}$ to remove honey solution before implantation. Previously, the tunica fragment has been considered contamination free after morphological and microbiological (culture) analysis. The xenograft was fixed to the bladder by a continuous absorbable (Polyglactin 910 5-0 thread) suture with stitching of all bladder layers. After the cystorrhaphy, the integrity of closure test by inflating the bladder with sterile $0.9 \% \mathrm{NaCl}$ solution was performed to verify possible extravasation points, followed by omentalization of xenograft placement site. Eventhough the S group had no xenograft implanted, all other surgery steps were proceeded same way as the $T$ 
group. Both groups laparorrhaphy and skin enclosure were performed using a simple pattern (non-absorbable monofilament 3-0 thread). Surgeries in groups T and S lasted about eight minutes. Figure 1 shows surgical steps for T group animals.

Postoperative therapy included topic chlorhexidine spray on surgical wound (every $24 \mathrm{~h}$ ), enrofloxacin ( $5 \mathrm{mg} / \mathrm{kg}$ SC every $24 \mathrm{~h}$ ), ketoprofen $(10 \mathrm{mg} / \mathrm{kg} \mathrm{SC}$ every $24 \mathrm{~h})$ and dipyrone $(100 \mathrm{mg} /$ $\mathrm{kg} \mathrm{SC}$ every $24 \mathrm{~h}$ ) for seven days. Animals were evaluated considering behavior and clinical aspects such as general condition, appetite, activity, surgical wound, defecation, urination and urine features. Animals were euthanized by inhalation of isoflurane overdose on post-surgical day 7 (subgroups T7 and S7), 15 (subgroups T15 and S15) and 30 (subgroups $\mathrm{T} 30$ and $\mathrm{S} 30)$.

Signs of peritonitis, adhesions, effusion and suture dehiscence were pursued during necropsy. Then, urinary bladders were excised and fixed in $10 \%$ buffered formalin solution, embedded in paraffin and cut in $5 \mu \mathrm{m}$ sections. Sections stained by hematoxylin and eosin (HE) and Gomori's trichrome were analyzed using a light microscope (Olympus ${ }^{\circledR}$ BX41). The slides were assessed by the same observer considering the following parameters: urothelization, inflammatory infiltrate and its constitution, neovascularization, muscular layer formation and graft integration to bladder tissue. These features were analyzed by comparison and graduated in absent $(-)$, rare $(+)$, low $(++)$, moderate $(+++)$ and high $(++++)$ levels.

Data finding concern clinical, macroscopic, and microscopic evaluations were descriptive analyzed.

\section{RESULTS AND DISCUSSION}

All the animals had full post-surgical recovery, becoming active and with appetite as soon as woke up from general anesthesia. None postoperative death was recorded. These results are similar to ALBRECHT et al. (2015) findings, but differ from POKRYWCZYNSKA et al. (2014) study, in which $50 \%$ of the rats underwent cystoplasty with synthetic membrane died; and from IIJIMA et al. (2007) that had $42 \%$ of rats deaths after cystoplasty with human amniotic membrane xenograft.

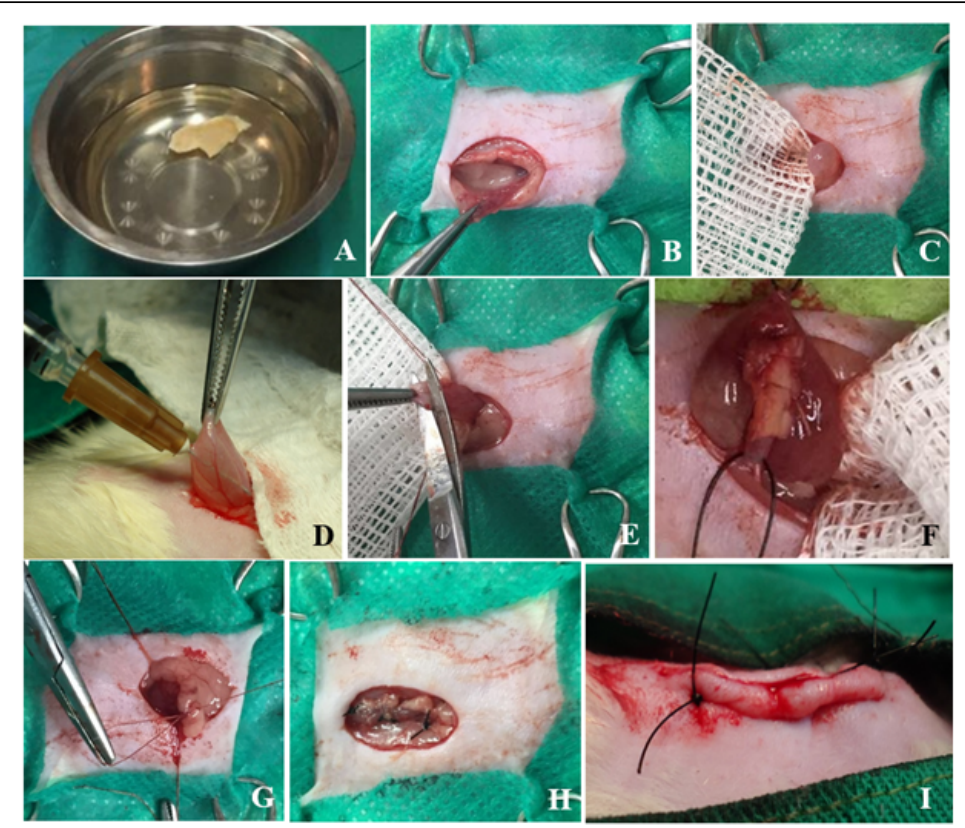

Figure 1 - T group surgical procedure of cystoplasty with bovine albugenous tunica as xenograft in Wistar rat. Sequence: (A) Graft hydration in $0.9 \%$ sodium chloride solution; (B) Median retro-umbilical longitudinal laparotomy; (C) Bladder exposure; (D) Cystocentesis; (E) Cistectomy; (F) Xenograft implantation; (G) Bladder omentalization; (H) Laparorraphy; (I) Dermorrhaphy. 
No animal had surgical wound complications, that is no local sensitivity, hyperthermia, suture dehiscence, behavior changes or any signs of infection or graft rejection as also seen by PINTO FILHO et al. (2015) in rabbits underwent bladder allograft. This fact can be related to an adequate surgical technique and to the tunica albuginea graft satisfactory consolidation with the receptor organ.

Two animals (from subgroups T7 and S7) had hematuria on the first three postoperative days and presented spontaneous resolution. It agrees with ROSSETTO et al. (2013) that also reported selflimiting hematuria in 9 out of 10 dogs submitted to bladder repair with swine intestinal submucosa (SIS).

At necropsy, crystals and urolithiasis were noted. One rat from T30 had a 1.0-cm-diameter calculus, while all others showed crystals. Crystals or urolithiasis were present in $80 \%(n=12 / 15)$ of $\mathrm{T}$ group rats and $46.66 \%(n=7 / 15)$ of $S$ group animals. Likewise, ROSSETTO et al. (2013)observed that more than half of them $\mathrm{S}$ group animals had bladder stones. ADAMOWICZ et al. (2012) used human amniotic membrane seeded with mesenchymal stem cells in rats' urinary bladder and reported urolithiasis formation in two of nine $\mathrm{T}$ group animals. A study with SIS and three types of silk-based biomaterials in rats cystoplasty determined urolithiasis in all experimental groups, including the $\mathrm{S}$ group (SETH et al., 2013). These data corroborate other research in which urinary calculus was frequent in bladder reconstructive surgeries with biodegradable acellular materialsin rats (ZHAO et al., 2015). FERREIRA et al. (2020) studied ovine tunica albuginea for cystoplasty in rats and interestingly reported crystals, mucus and calculus in 30 animals in which the uroliths and crystal formations were equally divided between the $\mathrm{S}$ and $\mathrm{T}$ groups, both sutured with polydioxanone threads, suggesting no exclusively correlation between crystals/calculi and tunica graft. KOSAN et al. (2008) and FERREIRA et al. (2020) attributed urolith formation to suture use. Our results suggested that crystals and calculus formation were related to Polyglactin 910 5-0 suture material, but also to the tunica implant given the fact that $\mathrm{T}$ animals were mainly affected. Considering literature reports urolithiasis seem to be a common complication of cystoplasty in rats whether or not using implants, we assume it was an expected find. Still, it is a frequent complication even in humans following augmentation cystoplasty (PALMER et al., 1993; KHOURY et al., 1997; KRONNER et al., 1998; SZYMANSKI et al., 2016). Mucus might have an important role in bladder stones genesis after augmentation, possibly acting as a nidus (KHOURY et al., 1997). An adequate management of rats stimulating water intake; and consequently, urination would possibly minimize this crystals and urolithiasis issue. In rats, we were unable to interfere in this process as we could more easily do with another animal such as a dog or even humans.

Several authors have reported a simple continuous pattern, the same as we used to suture the graft to the bladder wall and had no urine extravasation (ALBRECHT et al., 2006; OLIVEIRA et al., 2008; PINTO FILHO et al., 2015). However, IIJIMA et al. (2007) observed uroperitoneum followed by death with the same suture pattern.

Regards to adherence between the bladder and surrounding tissues noted at necropsy, all T7 rats ( $n=5 / 5)$ had this complication (between bladder and peritoneum); although, bladder omentalization was performed. This observation is in accordance with OLIVEIRA et al. (2008) and PINTO FILHO et al. (2015),in which all animals had some type of adhesion - to the peritoneum, omentum, rectum and small intestine- after cystoplasty. Moreover, 90\% of the human patients had adhesions post celiotomy (LIAKAKOS et al., 2001). The balance between fibrin deposition and its degradation is determinant in normal peritoneal healing. The low fibrinolytic activity at the surgical site leads to fibrin matrix cumulation, fibroproliferation and adhesions respectively (LIAKAKOS et al., 2001; ARUNG et al., 2011).

Histopathological evaluation showed vesical layers integrity (Figure 2A) and discrete inflammatory infiltrate in S7 subgroup rats $(n=5 / 5)$. Nevertheless, T7 animals had moderate inflammatory infiltrate, intense neovascularization and polymorphonuclear cells in periphery and interspersed in the graft (Figure 2B). It agrees with MORAES et al. (2017) that observed moderate inflammatory infiltrate in the same experimental model with swine tunica albuginea graft and contrasts with OLIVEIRA et al. (2008) that used bovine peritoneum in rabbits cystoplasty and found an intense mixed inflammatory infiltrate on implant periphery seven days after surgery. These findings denote a higher antigenic capacity of peritoneum compared to the tunica albuginea. Additionally, an initial urothelization was noted in T7 animals $(\mathrm{n}=$ 5/5). At the post-surgery period, ROTH et al. (2008) also remarked that early central graft urothelization and hyperplastic urothelial cells at SIS implant periphery region in rats. Alternatively, MORAES et al. (2017) reported continuous urothelization in swine tunica albuginea graft of the $\mathrm{T} 7$ rat group after cystoplasty. 


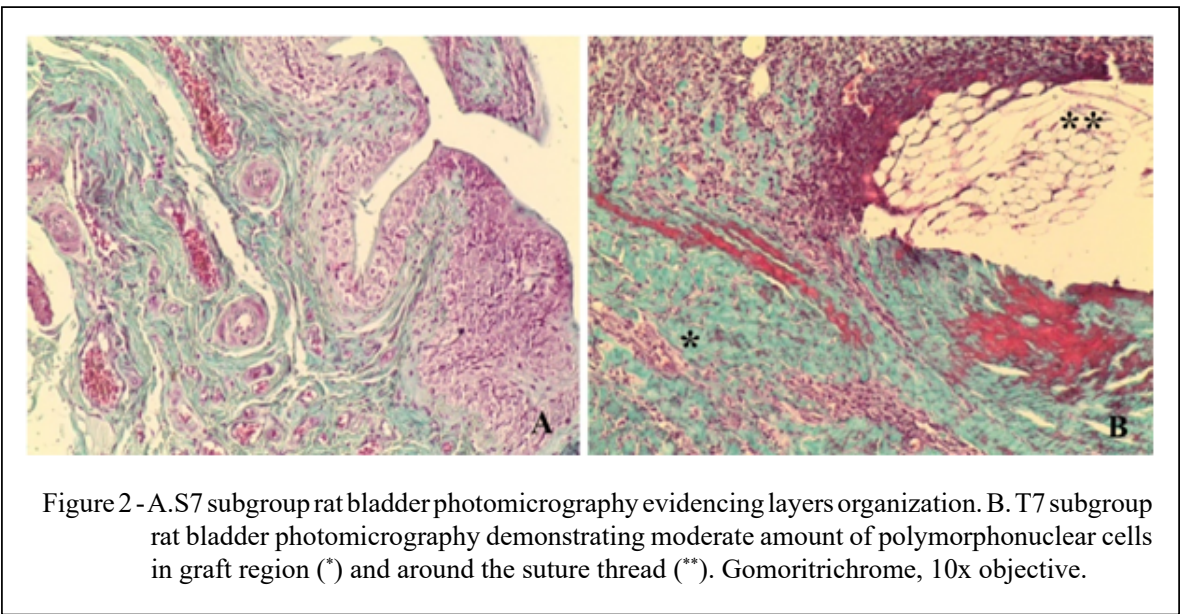

Histopathological analysis from S15 subgroup $(n=5 / 5)$ had regular bladder layers organization (Figure 3A) and discrete neovascularization. Concerning the T15 subgroup, all animals $(\mathrm{n}=5 / 5)$ presented bladder layer disorganization, even though urothelization and high vascularized lamina propria were verified. The same observations were described by ROTH et al. (2008) in rats underwent cystoplasty with SIS implant on 14 postoperative days. However, ZHAO et al. (2015) did not find urothelization in rats submitted to bladder augmentation with acellular matrix on 14 postoperative days. Still in T15 subgroup, we noted the initial phase of muscular layer formation in all rats $(\mathrm{n}=5 / 5)$ as well as verified by NUININGA et al. (2004) and ADAMOWICZ et al. (2012) after

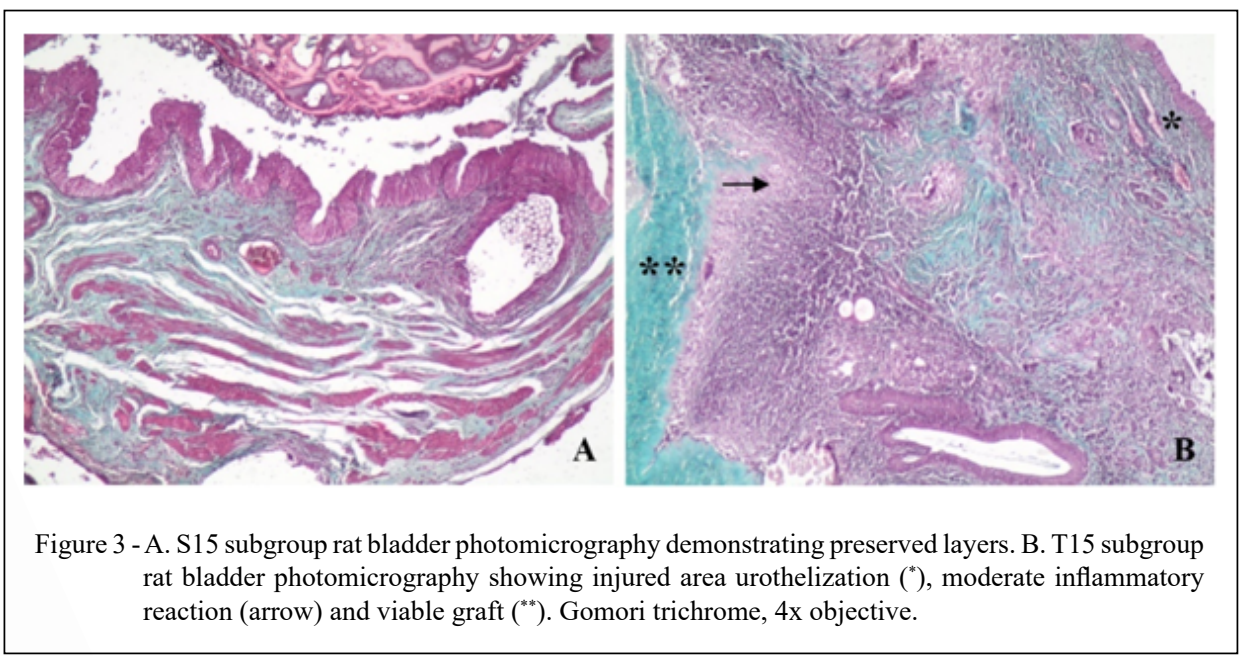

Ciência Rural, v.51, n.6, 2021. 
and higher levels of polymorphonuclear cells around the thread. MORAES et al. (2017) reported regenerated urothelium and well defined and cohesive layers with rare polymorphonuclear infiltrate in rats from $\mathrm{S}$ group 28 days after surgery. Regards to T30 subgroup, all rats $(n=5 / 5)$ had complete urothelialization on 30 postoperative days (Figure 4A). A study using human amniotic membrane in cystoplasty in rats on 30 post-surgery day reported uroplaquina-III positivity, which is a glycoprotein from superficial urothelial cells reported especially in advanced stages of urothelial differentiation (IIJIMA et al., 2007). A chronic inflammatory reaction around the implant was observed 30 days after surgery in dogs underwent cystoplasty with SIS (GRECA et al., 2004; OLIVEIRA et al., 2008). In our research and in the study by OLIVEIRA et al. (2008), the grafts were still viable without resorption (Figure 4B) what differs from GRECA et al. (2004) findings.

The presence of many smooth muscle fibers around the graft (ZHU et al., 2010) and advanced muscle layer organization (ALBRECHT et al., 2015) reported by other works differ from our results of muscle layer disorganization in rats from T30 subgroup. This difference in muscle layer formation may be inherent in the experimental model chosen, considering that ZHU et al. (2010) and ALBRECHT et al. (2015) used rabbits.

Table 1 exhibits urothelization, inflammation, neovascularization, muscular layer formation and graft absorption levels from $\mathrm{T}$ and $\mathrm{S}$ group rats at postoperative days 7, 15 and 30 .
Note that urothelization pattern was similar in both groups. Moreover, the muscular layer formation was present in $\mathrm{T}$ and $\mathrm{S}$, but more evident in the last one. Nevertheless, inflammatory infiltrate and neovascularization were remarkable more intense in $\mathrm{T}$ group rats.

A minimum graft absorption was noted in T30 animals, different from FERREIRA et al. (2020) reports of ovine tunica albuginea implant integrationto rats' bladder since 14 postoperative day. Our result might be related to bovine tunica thicker than ovine's one leading to a longer absorption time. In this regard, a long-term follow-up study must evaluate tunica absorption as well as graft rejection.

Apparently, clinical changes showed by $1 \mathrm{~T}$ group rat (hematuria) did not impair the incorporation of the graft into the urinary vesicle and it extends to all other $\mathrm{T}$ group animals. In this way, the bovine tunica albuginea proved to be an excellent substrate for bladder regeneration. The absence of rejection denotes its low antigenicity. This might be related to biomaterial composition that is essentially collagen. In both macroscopic and microscopic analysis, the graft was well attached to bladder wall with urothelization, which suggested that rejection did not occur until the moment evaluated (30 days). In addition, none of the animals in the $\mathrm{T}$ group showed clinical signs of rejection such as abdominal effusion, dehiscence, or pain.

The study of bovine tunica albuginea as xenograft in rats' bladders was motivated by the lack
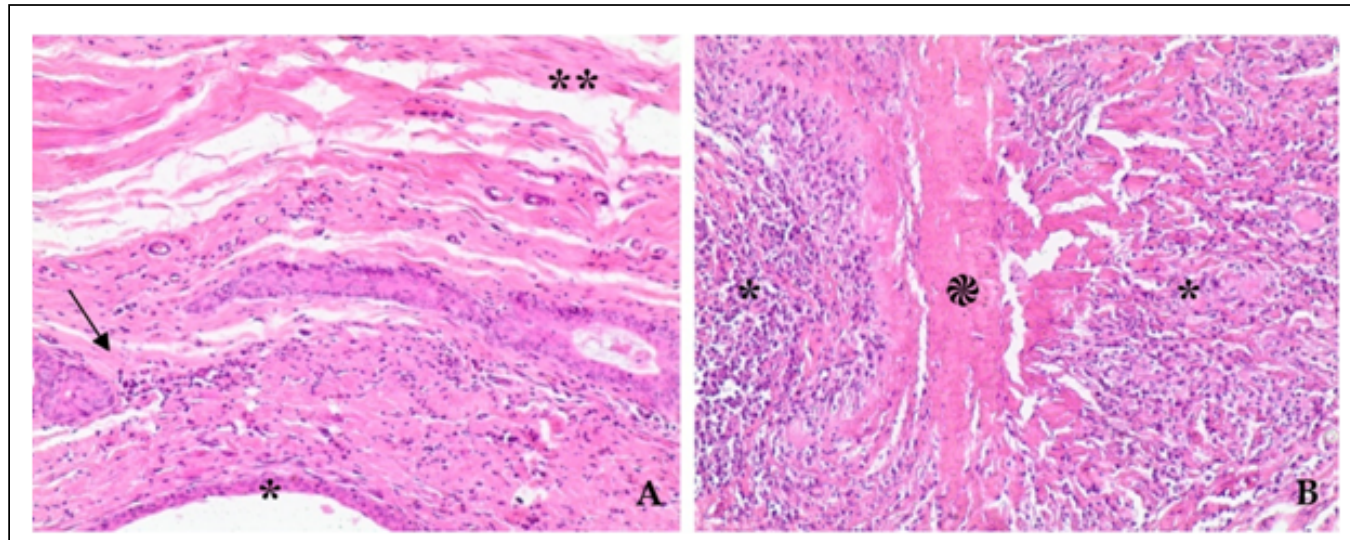

Figure 4 - A. T30 subgroup rat bladder photomicrography showing complete urothelization (*), moderate inflammatory reaction (arrow) and muscular layer formation $\left({ }^{* *}\right)$ B. T30 subgroup rat bladder photomicrography demonstrating graft (æ) invasion by large number of polymorphonuclear cells $\left({ }^{*}\right)$. HE, 10x objective. 
Table 1 - Evaluation of urothelization, inflammation, neovascularization, muscular layer formation and graft absorption from $\mathrm{T}$ and $\mathrm{S}$ group animals at postoperative days 7,15 and 30 .

\begin{tabular}{|c|c|c|c|c|c|c|}
\hline Group & Subgroup & Urothelization & $\begin{array}{l}\text { Inflammatory } \\
\text { Infiltrate }\end{array}$ & Neovascularization & $\begin{array}{c}\text { Muscular } \\
\text { layerformation }\end{array}$ & $\begin{array}{c}\text { Graft } \\
\text { absorption }\end{array}$ \\
\hline \multirow{3}{*}{$\mathrm{T}$} & $\mathrm{T} 7$ & ++ & +++ & ++++ & + & - \\
\hline & $\mathrm{T} 15$ & +++ & +++ & +++ & ++ & - \\
\hline & $\mathrm{T} 30$ & ++++ & +++ & +++ & +++ & + \\
\hline \multirow{3}{*}{ S } & S7 & ++ & + & ++ & ++ & NA \\
\hline & $\mathrm{S} 15$ & ++++ & + & + & ++++ & NA \\
\hline & $\mathrm{S} 30$ & ++++ & + & + & ++++ & NA \\
\hline
\end{tabular}

Absent (-); Rare (+); Low $(++)$; Moderate $(+++)$; High levels $(++++)$; NA: Not Applicable.

of reports in this experimental model. The biomaterial availability, easy handling and low cost reinforce the importance of further studies of the applicability of this biomembrane in bladder repair surgery routine.

\section{CONCLUSION}

Bovine tunica albuginea graft was successful in repairing rats' bladder without rejection being a good biomaterial option in reconstructive urinary vesicle surgeries. Honey has proven to be an efficient graft conservation method. Furthermore, studies involving bovine tunica albuginea grafts in rats also represent various animal models to comparative studies with human beings and other species.

\section{ACKNOWLEDGEMENTS}

This study was supported by Coordenação de Aperfeiçoamento de Pessoal de Nível Superior (CAPES) of the Brazilian Ministry of Education.

\section{BIOETHICS AND BIOSSECURITY COMMITTEE APPROVAL}

This study was approved by the Ethics Committee on Use of Animals of Universidade Federal Fluminense (UFF) with verdict number 852/16.

\section{DECLARATION OF CONFLICTS OF INTERESTS}

The authors declare no conflict of interest. The founding sponsors had no role in the design of the study; in the collection, analysis, or interpretation of data; in the writing of the manuscript, and in the decision to publish the results.

\section{AUTHORS' CONTRIBUTIONS}

All authors contributed for the conception and writing of the manuscript. All authors critically revised the manuscript and approved the final version.

\section{REFERENCES}

ABRAMOV, V. G.; MARKICHEVA, N. A. Therapeutic lamellar keratoplasty with honey preserved material. Oftalmologicheskii Zhurnal, v.38, n. 2, p. 81-83, 1983.

ADAMOWICZ, J. et al. Morphological and urodynamic evaluation of urinary bladder wall regeneration: muscles guarantee contraction but not proper function - a rat model research study. Transplantation Proceedings, v.44, n. 5, p. 1429-1434, 2012. Available from: <https://www.sciencedirect.com/science/article/ abs/pii/S0041134512003570?via\%3Dihub>. Accessed: May, 26, 2020. doi: 10.1016/j.transproceed.2012.01.144.

ALBRECHT, R. et al. Aplicação de cola de fibrina autóloga e cola de N-Butil-Cianoacrilato com implante de pericárdio suínoem cistoplastia experimental em coelhos (Oryctolaguscuniculus). Revista Portuguesa de Ciências Veterinárias, v.110, n.595, p.215-220, 2015. Available from: <http://www.fmv.ulisboa.pt/ spcv/PDF/pdf12_2015/215-220.pdf $>$. Accessed: May, 26, 2020.

ALIEVI, M. M. et al. Implante ósseo cortical alógeno conservado em mel na reconstrução de falha óssea diafisária em fêmur de cães: avaliação clínica e radiográfica. Ciência Rural, v.37, n.2, p.450-457, 2007. Available from: <https://www.scielo.br/scielo. php?script $=$ sci_arttext\&pid $=$ S0103-84782007000200024\&lng $=$ pt\&tlng=pt $>$. Accessed: May, 26, 2020. doi: 10.1590/S010384782007000200024 .

ARUNG, W. et al. Pathophysiology and prevention of postoperative peritoneal adhesions. World Journal of Gastroenterology, v.17, n.41, p.4545-4553, 2011. Available from: <https://www.ncbi.nlm nih.gov/pmc/articles/PMC3225091/>. Accessed: May, 26, 2020. doi: 0.3748/wjg.v17.i41.4545. 
FARIA, B. G. O et al. Túnica vaginal autógena para herniorrafia perineal em cães. Arquivo Brasileiro de Medicina Veterinária e Zootecnia, v.72, n.2, p.323-331, 2020. Avaiable from: <https:// www.scielo.br/pdf/abmvz/v72n2/0102-0935-abmvz-72-02-323. pdf>. Accessed: May, 28, 2020. doi: 10.1590/1678-4162-10520.

FERREIRA, M. L. G. et al. Estudo comparativo entre os fios de ácido poliglicólico e poliglactina na ileocistoplastia em cães (Canis familiaris). Revista Brasileira de Ciência Veterinária, v.12, n.1/3, p.84-88, 2005. Available from: <https://periodicos.uff.br/ rbcv/article/view/7188>. Accessed: May, 26, 2020. doi: 10.4322/ rbcv.2014.309.

FERREIRA, M. P. et al. Surgical management of long bone fractures in cats using cortical bone allografts preserved in honey. The Canadian Veterinary Journal, v.59, n.4, p.393396, 2018. Available from: <https://europepmc.org/article/ MED/29606726\#free-full-text>. Accessed: May, 26, 2020.

FERREIRA, N. N. et al. Ovine tunica albuginea as Xenograft for Cystoplasty in Rats. Acta Scientific Veterinary Sciences, v.2, n.7, p.56-61, 2020. Available from: <https://actascientific.com/ASVS/ ASVS-02-0082.php>. Accessed: Sep. 8, 2020.doi: 10.31080/ ASVS.2020.02.0082.

GRECA, F. H. et al. Retalho de submucosa de intestino delgado autólogo para aumento da capacidade vesical da bexiga: estudo experimental em cães. Revista do Colégio Brasileiro de Cirurgiões, v.29, n.5, p.294-299, 2002. Available from: <https://www.scielo.br/scielo.php?pid=S0100$69912002000500009 \&$ script $=\mathrm{sci}$ arttext\&tlng $=\mathrm{pt}>$. Accessed: May, 26, 2020. doi: 10.1590/S0100-69912002000500009.

GRECA, F. H. et al. Utilização da submucosa de intestino delgado porcino como retalho para aumento da capacidade vesical em cães. Acta Cirúrgica Brasileira, v.19, n.6, p.670676, 2004. Available from: <https://www.scielo.br/scielo. php? script $=$ sci_arttext\&pid $=$ S0102-86502004000600015\&lng $=$ pt\&tlng=pt $>$. Accessed: May, 26, 2020. doi: 10.1590/S010286502004000600015 .

JUNQUEIRA L. C.; CARNEIRO J. Histologia Básica. 13.ed. Rio de Janeiro: Guanabara Koogan, 2017. 554p.

KHOURY, A. E. et al. Stone Formation After Augmentation Cystoplasty: The Role of Intestinal Mucus. The Journal of Urology, v.158, n.3, p.1133-1137, 1997. Available from: <https:// doi.org/10.1016/S0022-5347(01)64404-5>. Accessed: Sep. 12, 2020. doi: 10.1016/S0022-5347(01)64404-5.

KOSAN, M. et al. Tissue reactions of suture materials (polyglactine 910 , chromed catgut and polydioxanone) on rat bladder wall and their role in bladder stone formation. Urological Research, v.36, n.1, p.43-49, 2008. Available from: <https://link.springer.com/ article/10.1007/s00240-007-0124-2>. Accessed: May, 26, 2020. doi: $10.1007 / \mathrm{s} 00240-007-0124-2$.

KRONNER, K. M. et al. Bladder calculi in the pediatric augmented bladder. The Journal of Urology, v.160, n.3, p.1096-1098, 1998 Available from: $<$ https://doi.org/10.1016/S0022-5347(01)62707-1>. Accessed: Sep. 12, 2020. doi: 10.1016/S0022-5347(01)62707-1.

LI, J. et al. In vitro culture of rat hair follicle stem cell on rabbit bladder acellular matrix. Springer Plus, v.5, n.1, p.1-7, 2016. Available from: $<$ https://link.springer.com/article/10.1186/s40064-016-3152-y>. Accessed: May, 27, 2020. doi: 10.1186/s40064-016-3152-y.
LIAKAKOS, T. et al. Peritoneal adhesions: etiology, pathophysiology, and clinical significance. Recent advances in prevention and management. Digestive Surgery, v.18, n.4, p.260-273, 2001. Available from: <https://www.researchgate. net/profile/Theodoros_Liakakos/publication/246588984 Peritoneal_Adhesions_Etiology_Pathophysiology_and_Clinical_ Significance/links/53ece 1 f90cf2981 ada 10 faa3/PeritonealAdhesions-Etiology-Pathophysiology-and-Clinical-Significance. pdf $>$. Accessed: May, 27, 2020. doi: 10.1159/000050149.

IIJIMA, K. et al. Transplantation of preserved human amniotic membrane for bladder augmentation in rats. Tissue Engineering, v.13, n.3, p.513-524, 2007. Available from: <https://www. liebertpub.com/doi/abs/10.1089/ten.2006.0170>. Accessed: May, 27, 2020. doi: 10.1089/ten.2006.0170.

MEDEIROS, F. F. L. et al. Heterologous bovine Tunica Albuginea Graft Conserved in Honey as Abdominal Wall Reinforcement in Rats. Open Journal of Veterinary Medicine, v.10, n.8, p.139153, 2020. Available from: <https:/www.scirp.org/journal/ paperinformation.aspx?paperid $=102495>$. Accessed: Sep. 15, 2020. doi: 10.4236/ojvm.2020.108012.

MORAES, T. A. et al. Avaliação morfofuncional do enxerto de túnica albugínea suína na cistoplastia em ratos. Arquivo Brasileiro de Medicina Veterinária e Zootecnia, v.69, n.4, p.9116-9118, 2017. Available from: <https:/www.scielo.br/scielo.php?pid=S0102$09352017000400973 \&$ script $=$ sci_arttext\&tlng $=p t>$. Accessed: May, 27, 2020. doi: 10.1590/1678-4162-9116.

NUININGA, J. E. et al. A rabbit model to tissue engineer the bladder. Biomaterials, v.25, n.9, p.1657-1661, 2004. Available from: $\quad<$ https://www.sciencedirect.com/science/article/pii/ S0142961203005192>. Accessed: May, 27, 2020. doi: 10.1016/ S0142-9612(03)00519-2.

OLIVEIRA, T. C. et al. Cistoplastia experimental em coelhos (Oryctolaguscuniculus) com peritônio bovino conservado em glicerol 98\%. Ciência Rural, v.38, n.8, p.2218-2224, 2008. Available from: <https://www.scielo.br/scielo.php?pid=S010384782008000800020\&script $=$ sci_arttext $>$. Accessed: May, 27, 2020. doi: 10.1590/S0103-84782008000800020.

OLIVEIRA, L. L. et al. Avaliação histológica da túnica albugínea bovina como biomaterial conservada em glicerina a $98 \%$ e em glutaraldeído a 0,625\%. Revista Brasileira de Medicina Veterinária, v.37, n.4, p.309-315, 2015.Available from: <http://rbmv.org/index. php/BJVM/article/view/415/304>. Accessed: May, 27, 2020.

PALMER, L. S. et al. Urolithiasis in Children Following Augmentation Cystoplasty. The Journal of Urology, v.150, n.2, p.726-729, 1993. Available from: $<$ https://doi.org/10.1016/S00225347(17)35598-2>. Accessed: Sep. 12, 2020. doi: 10.1016/S00225347(17)35598-2.

PINTO FILHO, S. T. L. et al. Avaliações clínica, ecográfica e anatomofisiológica do alotransplante parcial de vesícula urinária com células-tronco mesenquimaisalogênicas derivadas do tecido adiposo em coelhos. Arquivo Brasileiro de Medicina Veterinária e Zootecnia, v.67, n.5, p.1304-1312, 2015. Available from: <https://www.scielo.br/scielo.php?pid=S010209352015000501304\&script=sci_arttext $>$. Accessed: May, 27, 2020. doi: 10.1590/1678-4162-8148.

POKRYWCZYNSKA, M. et al. Is the Poly (L-Lactide-coCaprolactone) nanofibrous membrane suitable for urinary bladder 
regeneration? PLoS ONE, v.9, n.8, e105295, 2014.Available from: $<$ https://www.ncbi.nlm.nih.gov/pmc/articles/PMC4146509/> Accessed: May, 27, 2020. doi: 0.1371/journal.pone.0105295.

QUEIROZ, F. F. et al. Ensaio biomecânico da túnica albugínea bovina conservada em glicerina $98 \%$ para utilização como membrana biológica. Ciência Rural, v.42, n.3, p.501-506, 2012. Available from: <https://www.scielo.br/scielo.php?pid=S010384782012000300019\&script $=$ sci_arttext $>$. Accessed: May, 27, 2020. doi: 10.1590/S0103-84782012000300019.

ROSSETTO, V. J. V. et al. Grafts of Porcine small intestinal submucosa seeded with cultured homologous smooth muscle cells for bladder repair in dogs. Acta Veterinaria Scandinavica, v.55, n.1, p.1-6, 2013. Available from: < https://actavetscand. biomedcentral.com/articles/10.1186/1751-0147-55-39>. Accessed: May, 27, 2020. doi: 10.1186/1751-0147-55-39.

ROTH, C. C. et al. Temporal differentiation and maturation of regenerated rat urothelium.BJU International, v.103, n.6, p.836841, 2008. Available from: <https://bjui-journals.onlinelibrary. wiley.com/doi/full/10.1111/j.1464-410X.2008.08231.x>. Accessed: May, 27, 2020. doi: 10.1111/j.1464-410X.2008.08231.x.

SANTOS, I. F. C. Mel e açúcar mascavo na cicatrização de feridas. Ciência Rural, v.42, n.12, p.2219-2224, 2012. Available from: $<$ https://www.scielo.br/scielo.php?pid=S010384782012001200018\&script=sci_arttext $>$. Accessed: May, 27,2020. doi: 10.1590/S0103-84782012001200018.

SETH, A. et al. The performance of silk scaffolds in a rat model of augmentation cystoplasty. Biomaterials, v.34, n.20, p.4758-4765,
2013. Available from: <https://www.sciencedirect.com/science/ article/pii/S0142961213003487>. Accessed: May, 27, 2020. doi: 10.1016/j.biomaterials.2013.03.038

SUBRAHMANYAM, M. Storage of skin grafts in honey. Lancet v.341, n.1, p.63-64, 1993. doi: 10.1016/0140-6736(93)92547-.

SZYMANSKI, K. M. et al. Bladder stones after bladder augmentation are not what they seem. Journal of Pediatric Urology, v.12, n.2, p.98.E1-98.E6, 2016. Available from: <https:// doi.org/10.1016/j.jpurol.2015.06.021>. Accessed: Sep. 12, 2020. doi: 10.1016/j.jpurol.2015.06.021.

WONGSETTHACHAI, P. et al. Urinary bladder substitution using autologous tunica vaginalis in male dogs. Research in Veterinary Science, v.90, n.1, p.156-159, 2011. Available from: $<$ https://www. sciencedirect.com/science/article/abs/pii/S0034528810001840>. Accessed: May, 27, 2020. doi: 10.1016/j.rvsc.2010.05.015.

ZHAO, Y. et al. Time-dependent bladder tissue regeneration using bilayer bladder acellular matrix graft-silk fibroin scaffolds in a rat bladder augmentation model. Acta Biomaterialia, v.23, n.1, p.91-102, 2015. Available from: <https://www.sciencedirect.com/ science/article/abs/pii/S1742706115002561>. Accessed: May, 27, 2020. doi: 10.1016/j.actbio.2015.10.033.

ZHU et al. Bladder reconstruction with adipose-derived stem cell-seeded bladder acellular matrix grafts improve morphology composition. World Journal of Urology, v.28, n.1, p.493-498, 2010. Available from: <https://link.springer.com/article/10.1007/s00345-010-0508-8>. Accessed: May, 27, 2020. doi: 10.1007/s00345-010-0508-8. 